\title{
DIRASAH
}

Volume 3, Number 2, Agustus 2020

p-ISSN: 2615-0212 | e-ISSN: 2621-2838

https://ejournal.iaifa.ac.id/index.php/dirasah

\begin{tabular}{|c|c|c|}
\hline Accepted: & Revised: & Published: \\
April 2020 & Mei 2020 & Agustus 2020 \\
\hline
\end{tabular}

\section{Konsep Model Problem Based Learning pada Pembelajaran IPS dalam Melatih Kemampuan Berpikir Kreatif Siswa}

\author{
Ahmad Yunus ${ }^{1}$, Khoirul Inayah ${ }^{2}$ dan Durrotun Nafisah ${ }^{3}$ \\ IAIN Salatiga, Salatiga, Indonesia \\ Email: ${ }^{1}$ a.yunus76@gmail.com, ${ }^{2}$ nararya@gmail.com dan \\ bunafisumineais@gmail.com
}

\begin{abstract}
This study aims to provide a conceptual description of the problem based learning model in training students' critical thinking skills. Social studies education is essentially studying humans as social creatures in their lives. As part of the learning process, the concept of problem based learning comes to train students to stimulate curiosity, so that finally it can stimulate students to think critically. The research method used in this study is the study of literature relating to the results of previous studies. The conclusion from the results of the research that is used as a reference in this study is problem based learning $(P B L)$ can improve students' creative abilities. The research method used in this study is the study of literature relating to the results of previous studies. The conclusion from the results of the research that is used as a reference in this study is problem based learning (PBL) can improve students' creative abilities.
\end{abstract}

Keywords: Problem based learning, creative thinking, social studies 


\section{Abstaksi}

Penelitian ini bertujuan untuk memberikan gambaran konseptual tentang model pembelajaran problem based learning dalam melatih kemampuan berpikir kristis siswa. Pendidikan IPS pada hakikatnya mempelajari manusia sebagai makhluk sosial dalam kehidupannya.Sebagai bagian dari proses pembelajaran, konsep problem based learning hadir melatih siswa untuk merangsang rasa ingin tahu, sehingga akhirnya mampu menstimulus siswa untuk berfikir kritis. Metode penelitian yang digunakan dalam penelitian ini yaitu studi literatur yang berkaitan dengan hasil penelitian-penelitian terdahulu. Kesimpulan dari hasil penelitian yang menjadi acuan pada penelitian ini adalah problem based learning (PBL) dapat meningkatkan kemampuan kreatif siswa. Metode pengujian menggunakan studi kasus permasalahan lingkungan di sekitar siswa.Hasil yang diperoleh menunjukkan pembelajaran berbasis masalah berpengaruh positif terhadap kemampuan berfikir kreatif.

Kata kunci: Problem based learning, berpikir kreatif, IPS

\section{Pendahuluan}

Ilmu pengetahuan sosial adalah sekelompok disiplin akademisi yang mempelajari aspek-aspek yang berhubungan dengan manusia dan lingkungan sosialnya.Berbeda dengan ilmu pengetahuan alam yang lebih ilmiah, ilmu pengetahuan sosial dalam mempelajari aspek-aspek masyarakat secara subjektif, intersubjektif, dan objektif.

Menurut Gunawan R sistem pembelajaran IPS seharusnya mengikuti perkembangan yang terjadi di dunia secara global. Jika tidak demikian dan meneruskan pembelajaran yang menekankan pada teori tanpa mengetahui proses berfikir maka pembelajaran IPS tidak akan mampu membantu siswa agar dapat hidup secara efektif dan produktif. Masalah yang terjadi di lapangan adalah pembelajaran IPS didominasi dengan mengunakan metode ceramah.Kondisi ini dianggap membosankan yang berdampak mengurangi motivasi belajar bagi siswa didik, berdasarkan analisa rumusan KBM (Kegiatan Belajar Mengajar). ${ }^{1}$

Proses pembelajaran Pendidikan IPS, menempatkan guru sebagai sumber dominan disamping terbatasnya penggunaan sumber daya belajar lainnya. Selain itu, kelemahan pembelajaran IPS menempatkan kemampuan kognitif di tingkat rendah.Sehingga kemampuan berfikir siswa tidak berkembang ke

\footnotetext{
${ }^{1}$ R Gunawan, Pendidikan IPS (Bandung: Alfabeta, 2013).
} 
tingkat yang lebih tinggi. Dampaknya siswa menjadi kurang berfikir aktif dan hanya mempelajari apa yang disedikan oleh buku dengan giat menghafal tanpa tahu prosesnya.

Belajar menurut Grendler hakikatnya merupakan proses interaksi terhadap semua situasi yang ada di lingkungan sekitar, hasil dari representasi yang di akuisisi sebagai pedoman untuk perilaku di masa depan. Peran guru sangat diharapkan dalam membantu siswa supaya aktif dalam proses pembelajaran. Istilah pembelajaran dapat dimaknai dengan upaya untuk memberi pelajaran seseorang atau kelompok melalui berbagai upaya dan strategi, metode danpendektan-pendekatan yan dapat diupayakan pada tujuan yang telah direncanakan. ${ }^{2}$

Strategi pada proses pembelajaran disebut dengan strategi pembelajaran. Dengan strategi pembelajaran yang digunakan oleh guru untuk menyampaikan materi pembelajaran sehingga akan memudahkan siswa menerima dan memahami materi pembelajaran. Akhirnya siswa mampu menguasi pembelajaran sampai akhir kegiatan belajar.

Costa, dkk., yang dikutip oleh Supardan dalam bukunya strategi pembelajaran dikelompokkan menjadi empat macam, diantaranya; (1) stretegi pembelajaran direktif yaitu pembelajaran berorientasi pada penguasaan materi yang digunakan guru saat mengajar supaya siswa lebih cepat paham; (2) strategi pembelajaran mediatif yaitu proses rasional pemecahan masalah, atau pengambilan keputusan dengan berfiir secara kritis dan induktif; (3) strategi generative yaitu strategi belajar yang mendorong siswa untuk belajar kreatif sehingga menghasilkan pemikiran baru dan berguna, misalnya strategi problem solving: (4) strategi pembelajaran kolaboratif yaitu pembelajaran membentukkelompok dengan menggabungkna pemikiran bersama-sama agar berhasil menyelesaikan tugas. $^{3}$

Bagian kedua yang bisa dipakai pada proses pembelajaran setelah strategi adalah model. Konsep penggunaan model sendiri bertujuan untuk memperbaiki strategi pembelajaran guru. Menurut Trianto yang dikutip oleh Rojuli dalam bukunya mengemukakan model pembelajaran yang bisa diterapkan ada tiga, diantarnya; (1) model integrasi berdasarkan topik yiatu model pembelajaran dengan mengambil satu topik kemudian dikaitkan dengan berbagai disiplin

\footnotetext{
${ }^{2}$ M.E Glender, Learning and Intruction (Jakarta: Kencana, 2011).

${ }^{3}$ Supardan, Pendidikan IPS (Bandung: Bumi Aksara, 2015).
}

Dirasah, Vol. 3, No.2, Agustus 2020 
ilmu; (2) model integrasi berdasarkan potensi umum, yaitu model pembelajaran dengan mengembangkan ips berdasarkan potensi yang berada di wilayah sekitar; (3) model integrasi berdasarkan masalah atau Problem based learning (PBL), yaitu pembelajaran yang menggunakan permasalahan kemudian dilanjutkan memberikan sudut pandang penyebabnya serta solusi yang bisa diterapkan. Salah satu model pembelajaran yang akan dibahas kali ini adalah Problem based learning (PBL). ${ }^{4}$

Menurut Barrows dan Kelson dalam materi pelatihan penerapan metode PBL di IBII yang dikutip oleh Amir PBL adalah sebuah kurikulum dalam proses pembelajaran dengan menjadikan masalah sebagai acuan untuk mendapatkan pengetahuan penting serta menjadikan siswa mahir dalam memecahkah masalah.Fokus model belajar PBL mengidentifikasi isu pembelajaran untuk memecahkan masalah. Semakin nyata masalah yang dijadikan bahan pembelajaran, maka semakin baik pengaruhnya pada tingkat kecakapan belajar.Selain itu, pembelajaran mengunakan model PBL memfasilitasi siswa mengkontruksi pengetahuan secara mandiri ataupun kelompok. $^{5}$

Keunggulan PBL terletak pada perancangan masalah, sebab masalah yang diberikan diharapkan dapat memberikan rangsangan pemicu siswa untuk belajar dengan baik. Masalah dapat dikatakan baik unuk pembelajaran jika memiliki ciri khas, menurut Wee dalam Amir, sebagai berikut; (1) Punya keaslian seperti di dunia kerja, (2) dibangun dengan memperhitungkan pengetahuan sebelumnya, (3) membangung pemikiran yang metakognitif dan konstruktif, (4) meningkatkan minat dan motivasi dalam pembelajaran. ${ }^{6}$

Tujuan penulisan adalah untuk mengkaji beberapa penelitian-penelitian terdahulu yang berkaitan dengan model PBL. Metode penelitian yang digunakan dalam penelitian ini yaitu studi literatur yang berkaitan dengan hasil penelitian-penelitian terdahulu. Hasil kajian nantinya diharapkan dapat menjadi rujukan penelitian tentang konsep model PBL dalam proses pembelajaran IPS.

\footnotetext{
${ }^{4}$ Subkhan Rojuli, Strategi Pembelajaran Pendidikan IPS (Surabaya: Garuda Mas Sejahtera, 2016).

${ }^{5}$ M.Taufik Amir, Inovasi Pendidikan Melalui Problem Based Learning (Bagaimana Pendidik Memberdayakan Pemelajar Di Era Pengetahuan) (Jakarta: Kencana, 2016).

${ }^{6}$ Ibid.
} 


\section{Hasil dan Kajian}

Penelitian yang dilakukan oleh Darmawan bertujuan untuk memperoleh sebuah gambaran mengenai adanyaperanan pengembangan pembelajaran berbasis masalah dalam meningkatkan kemampuan berfikir siswa.Penelitian ini dilaksanakan di MI Darussa'adah Pandeglang, terhadap 30 siswa yang menjadi responden penelitian.Pada penelitian ini pula berhasil menemukan berbagai dimensi pembelajaran IPS SD dan memberikan rekomendasi yang diperlukan, baik secra konseptual maupun yang bersifat praktis.Kesimpulan penelitian menunjukkan keterkaitan antara pola pembelajaran berbasis kritis, memberikan kontribusi bagi keberhasilan guru dalam menggunakan pola pembelajaran tersebut. $^{7}$

Penelitian yang dilakukan oleh Mu'aini membahas tentang peningkatan kualitas pembelajaran IPS melalui Penerapan Metode Problem based learning serta bertujuan memperbaiki kualitas praktik pembelajaran di kelasnya. Penelitian ini merupakan penelitian tindakan dengan 35 responden sebagai subjek penelitian di SMP Negeri 15 Kota Yogyakarta.Berdasarkan hasil penelitian dapat disimpulkan bahwa penerapan metode pembelajaran berbasis masalah dapat meningkatkan kualitas ilmu sosial pembelajaran di kelas. ${ }^{8}$

Penelitian yang dilakukan oleh Risvirenol tentang pengaruh strategi pembelajaran berbasis masalah terhadap hasil belajar mahasiswa yang memiliki gaya kognitif yang berbeda, serta bertujuan untuk memberikan strategi tentang komponen utama dlam mengarahkan proses pembelajaran yang berdampak baik pada proses belajar siswa. Subjek penelitian adalah mahasiswa program studi Pendidikan bahasa dan sastra Indonesia semester III yang menempuh matakuliah pengembangan peserta didik dengan 80 responden.Hasil penelitian menunjukkan bahwa nilai hasil belajar pada mahasiswa yang memiliki kognitif berbeda masuk dalam kategori baik. Sehingga dapat disimpulkan terdapat

\footnotetext{
${ }^{7}$ Darmawan, "Penggunaan Pembelajaran Berbasis Masalah Dalam Meningkatkan Kemampuan Berpikir Kritis Siswa Pada PEmbelajaran IPS Di MI Darussa'adah Pandeglang,” Jurnal Penelitian Pendidikan 11, no. 2 (2010): 22-29.

${ }^{8}$ Mu'aini, "Peningkatan Kualitas Pembelajaran IPS Melalui Penerpaan Metode Problem Based Learning Di SMP Negeri 15 Kota Yogyakarta,” JIPSINDO 1, no. 3 (2016): 44-62.
}

Dirasah, Vol. 3, No.2, Agustus 2020 
interaksi yang signifikan antara strategi pembelajaran dan gaya kognitif terhadap hasil belajar. ${ }^{9}$

Penelitian yang dilakukan oleh Ahmad Khoirussyifa, Amrullah, Muslimin Ibrahim, dan wahono Widodo tentang implementasi pembelajaran berbais masalah untuk melatihkan kemampuan berfikir kreatif dan penguasaan konsep. Penelitian ini bertujuan untuk mengetahui bagaima peningkatan ketrampilan berfikir kreatif dan penguasaan konsep siswa sekolah dasar setelah diterapkannya model pembelajaran berbasis masalah.Jenis penelitian yang digunakan adalah penelitian eksperimen semu yang dilaksanakan di SD N Kalirungkut IV Surabya dengan 80 siswa menjadi responden.Hasil penelitian menunjukkan nilai dari analisis $\mathrm{N}$-Gain Skore masuk dalam kategori sedang.Sehingga dapat ditarik kesimpulan pembelajaran menggunakan model pembelajaran PBL terlaksana dengan baik. ${ }^{10}$

Penelitian yang dilakukan oleh Murwantono Sukidjo tentang peningkatan hasil belajar IPS dengan model PBL berbantuan media stimulant gambar. Penelitian ini bertujuan untuk meningkatkan kualitas proses pembelajaran, meningkatkan aktivitas proses pembelajaran, meningkatkan sikap sosial peserta didik, dan meningkatkan hasil belajar IPS peserta didik melalui penerapan model pengajaran berbasis masalah berbantuan gambar. Penelitian ini merupakan penelitian tindakan kelas yang dilakukan di SMP N 1 Tepus, Guningkidul dengan 30 siswa menjadi responden. Hasil penelitian menunjukkan bahwa model PBL berbantuan media stimulan gambar merupakan strategi efektif dalam proses belajar mengajar.

Penelitian yang dilakukan oleh Frans Aditia Wiguna dan Susi Damayanti membahas tentang pengaruh model pembelajaran berbasis masalah terhadap kemampuan berpikir kreatif siswa pada pembelajaran IPS. Tujuan dalam penelitian adalah untuk mengetahui apakah model pembelajaran berbasis maslah berpengaruh terhadap kemmapuan berpikir kreatif siswa dalam

\footnotetext{
${ }^{9}$ Risvirenol, "Pengaruh Strategi Pembelajaran Berbasis Masalah Terhadap Hasil Belajar Mahasiswa Yang Memiliki Gaya Kognitif Berbeda," Jurnal Sains Dan Teknologi Tadulako 4, no. 1 (2005): 80-91.

${ }^{10}$ Ahmad. Khoirussyifa, "Implementasi Pembelajaran Berbasis Masalah Untuk Melatihkan Kemampuan Berfikir Kreatif Dan Penguasaan Konsep Siswa Kelas V Sekolah Dasar,” Jurnal Review Pendidikan Dasar 3, no. 1 (2017): 378-87.

${ }^{11}$ Murwantono Sukidjo, "Peningkatan Hasil Belajar IPs Dengan Model Problem Based Learning Berbantuang Media Stimulan Gambar,” Jurnal Pendidikan IPS 2, no. 1 (2016): 30-41.
} 
pembelajaran IPS materi ekonomi. Subjek penelitian ini adalah SDN Ngadirejo 3 dan 5 kota Kediri dengan masing-masing 35 siswa sebagai responden. Kesimpulan dari penelitian ini bahwa model pembelajaran berbasis masalah berpengaruh positif terhadap kemampuan berfikir kreatif pada pembelajaran IPS siswa. ${ }^{12}$

\section{Pembahasan}

Konsep pembelajaran dirancang pada akhirnya untuk dapat mengimbangi perkembangan pengetahuan sesuai kebutuhan pada era sekarang ini.Pembelajaran berbasis masalah merupakan upaya inovatif dalam meningkatkan kualitas pembelajaran.

Supaya lebih dalam memahami konsep PBL, pengertian PBL menurut Dutch dalam Amir problem based learning merupakan metode intruksional yang matang dengan mengutamakan belajar untuk belajar, serta bekerja sama untuk bisa mencari solusi masalah yang nyata. Pada model pembelajaran ini masalah dipersiapkan sebagai inisiatif materi pelajaran, dengan tujuan supaya siswa dapat berpikir kritis dan analitis. Selain itu, pembelajaran ini menekankan untuk bisa belajar kelompok, alasan utamanya supaya siswa dapat berbagi pengetahuan dan gagasan-gagasan serta melatih untuk bekerja sama. ${ }^{13}$

Hal yang sama juga diungkapkan oleh Susiloningrum, model problem based learning adalah model pembelajaran siswa aktif yang mengaitkan informasi baru dengan struktur kognitif yang telah dimiliki dan bermakna bagi siswa. Kemudian mencari solusi permasalahan yang nyata melalui kegiatan belajar kelompok atau diskusi untuk mengembangkan ketrampilan menyelesaikan masalah dengan bantuan berbagai sumber belajar.

Menurut Kamdi dalam Mu'aini problem based learning adalah suatu model pembelajaran yang melibatkan siswa untuk memecahkan masalah melalui tahap metode ilmiah sehingga siswa dapat mempelajari pengetahuan sekaligus memiliki ketrampilan memecahkan masalah. Model ini melibatkan peserta didik secara langsung dalam proses pembelajaran, baik dalam segi praktik maupun dalam segi pemikiran. Pada dunia pendidikan banyak kritik yang membahas tentang pembelajaran di kelas tidak memiliki manfaat pada

\footnotetext{
${ }^{12}$ Frans Aditia Wiguna and Susi Damayanti, "Pengaruh Model Pembelajran Berbasis Masalah Terhadap Kemampuan Berfikir Kreatif Siswa Pada Pembelajaran IPS Di SDN Ngadirejo

Kediri," Jurnal Pendidikan Dasar Nusantara 3, no. 2 (2017): 175-88.

${ }^{13}$ Amir, Inovasi Pendidikan Melalui Problem Based Learning (Bagaimana Pendidik Memberdayakan Pemelajar Di Era Pengetahuan).
}

Dirasah, Vol. 3, No.2, Agustus 2020 
kehidupan nyata.Untuk menanggapi isu tersebut model PBL mencoba membangun masalah yang syarat dengan konteks praktik, dengan begitu siswa dapat memiliki keterlibatan yang berguna dikehidupan nyata. ${ }^{14}$

Menurut Amir, pada proses PBL sarat dengan konsep yang mendidik dari pada hanya sekedar meminta peserta didik untuk mencari tahu hal yang spesifik. Model ini lebih mendorong peserta didik untuk melakukan observasi, mempertanyakan dan membuat hipotesis, dengan begitu peserta didik dapat mempertajam keingintahuan mereka (inquiry skill) yang mana lebih difokus kan pada proses bukan pada hasil semata. ${ }^{15}$

Smith secara khusus meneliti manfaat yang diperoleh peserta didik dari pembelajaran pada metode PBL, diantaranya; (1) menjadi lebih ingan dan meningkatkan materi atas materi ajar, (2) meningkatkan focus pada pengetahuan yang relevan, (3) mendorong untuk berpikir, (4) membangun kerja tim, kepemimpinan, dan ketrampilan sosial, (5) membangun kecakapan belajar, (6) memotivasi pemelajar.

Berdasarkan pada pembahasan yang telah dipaparkan diatas, model problem based learning pada hakikatnya adalah model pembelajaran yang menerapkan keaktifan siswa, dengan memberikan stimulus masalah pada kehidupan nyata. Hal ini akan bermakna bagi siswa sebagai bahan pembelajaran serta meningkatkan kecapan-kecakapan berfikir melalui kegiatan belajar kelompok atau dalam bentuk diskusi.

Pada penelitian sebelumnya, model problem based learning sangat direkomendasikan sebagai model pembelajaran. Model ini membantu siswa mengembangkan keterampilan berfikir, analisa maslaah, penyelesaian masalah, dengan mempelajari nilai-nilai yang terkandung pada kejadian lampau orang dewasa.

Hasil kajian terdahulu telah membuktikan bahwa penerapan model PBL pada proses pembelajaran IPS secara empiris terbukti mampu meningkatkan kemampuan berfikir kreatif siswaserta mampu menghasilkan solusi alternative dalam setiap permasalahan. Sehingga model ini sesuai dan dapat digunakan dalam proses pembelajaran di kelas.

\footnotetext{
${ }^{14}$ Mu'aini, "Peningkatan Kualitas Pembelajaran IPS Melalui Penerpaan Metode Problem Based Learning Di SMP Negeri 15 Kota Yogyakarta."

${ }^{15}$ Amir, Inovasi Pendidikan Melalui Problem Based Learning (Bagaimana Pendidik Memberdayakan Pemelajar Di Era Pengetahuan).
} 


\section{Kesimpulan}

Berdasarkan hasil pembahasan mengenai model problem based learning terhadap pembelajaran ips dari penelitian terdahulu yang telah dibahas di atas, penulis memiliki kesimpulan bahwa model problem based learning dapat melatih kemampuan berpikir siswa. Hal ini dikarenakan model problem based learning merupakan sutu model yang menuntut siswa untuk berfikir lebih luas dalam menganalisis masalah yang disajikan sebelumnya.

Berdasarkan penelitian terdahulu yang telah dikaji dan hasil refleksi membuktikan bahwa model problem based learning dapat diterapkan di berbagai jenjang pendidikan, serta pada pembelajaran IPS merupakan mata pelajaran yang mengkaji nilai sosial, dengan model problem based learning dinilai sesuai sebab model ini menggunakan masalah pada dunia nyata yang berada dilingkungan sekitar.

\section{Daftar Pustaka}

Amir, M.Taufik. Inovasi Pendidikan Melalui Problem Based Learning (Bagaimana Pendidik Memberdayakan Pemelajar Di Era Pengetahuan). Jakarta: Kencana, 2016.

Darmawan. "Penggunaan Pembelajaran Berbasis Masalah Dalam Meningkatkan Kemampuan Berpikir Kritis Siswa Pada PEmbelajaran IPS Di MI Darussa'adah Pandeglang." Jurnal Penelitian Pendidikan 11, no. 2 (2010): 22-29.

Glender, M.E. Learning and Intruction. Jakarta: Kencana, 2011.

Gunawan, R. Pendidikan IPS. Bandung: Alfabeta, 2013.

Khoirussyifa, Ahmad. "Implementasi Pembelajaran Berbasis Masalah Untuk Melatihkan Kemampuan Berfikir Kreatif Dan Penguasaan Konsep Siswa Kelas V Sekolah Dasar." Jurnal Review Pendidikan Dasar 3, no. 1 (2017): $378-87$.

Mu'aini. "Peningkatan Kualitas Pembelajaran IPS Melalui Penerpaan Metode Problem Based Learning Di SMP Negeri 15 Kota Yogyakarta." JIPSINDO 1, no. 3 (2016): 44-62.

Risvirenol. "Pengaruh Strategi Pembelajaran Berbasis Masalah Terhadap Hasil Belajar Mahasiswa Yang Memiliki Gaya Kognitif Berbeda." Jurnal Sains Dan Teknologi Tadulako 4, no. 1 (2005): 80-91. 
Rojuli, Subkhan. Strategi Pembelajaran Pendidikan IPS. Surabaya: Garuda Mas Sejahtera, 2016.

Sukidjo, Murwantono. "Peningkatan Hasil Belajar IPs Dengan Model Problem Based Learning Berbantuang Media Stimulan Gambar." Jurnal Pendidikan IPS 2, no. 1 (2016): 30-41.

Supardan. Pendidikan IPS. Bandung: Bumi Aksara, 2015.

Wiguna, Frans Aditia, and Susi Damayanti. "Pengaruh Model Pembelajran Berbasis Masalah Terhadap Kemampuan Berfikir Kreatif Siswa Pada Pembelajaran IPS Di SDN Ngadirejo Kediri." Jurnal Pendidikan Dasar Nusantara 3, no. 2 (2017): 175-88.

Copyright (C) 2020Journal Dirasah: Vol. 3, No.2,Agustus 2020, p-ISSN: 2615-0212, e-ISSN; 2621-2838

Copyright rests with the authors

Copyright of Jurnal Dirasah is the property of Jurnal Dirasah and its content may not be copied oremailed to multiple sites or posted to a listserv without the copyright holder's express writtenpermission. However, users may print, download, or email articles for individual use. https://ejournal.iaifa.ac.id/index.php/dirasah 